\title{
STUDI KEHIDUPAN PASIEN STROKE DENGAN PROLONGED BEDREST DI DESA PUCANGSIMO KECAMATAN BANDARKEDUNGMULYO KABUPATEN JOMBANG
}

\author{
The Study Of Stroke Patient Life With Prolonged Bedrest In Pucangsimo \\ Village, Bandarkedungmulyo, Jombang
}

\author{
Vivi Nur Azizah ${ }^{1)}$, Iswanto Karso ${ }^{2)}$, Ahmad Nur Khoiri ${ }^{3)}$ \\ Stikes Pemkab Jombang ${ }^{\text {I) }}$ S1 Keperawatan ${ }^{2)}$ Profesi Ners ${ }^{3)}$ \\ Email : vi2nurazizah@gmail.com
}

\begin{abstract}
ABSTRAK
Pendahuluan: Kecacatan akibat stroke tidak hanya berdampak bagi pasien, namun juga bagi anggota keluarga. Penelitian ini bertujuan untuk mengetahui bagaimana kehidupan (aktifitas sehari-hari, kondisi psikologis, kondisi sosial dan spiritual) pasien stroke dengan bedrest selama $>1$ tahun sangat perlu untuk di teliti, sehingga dapat diketahui bagaimana sesungguhnya kehidupan pasien stroke di rumah. Metode: Desain penelitian ini adalah kualitatif dengan pendekatan fenomenologi. Instrumen berasal dari peneliti sendiri dan subjek penelitian menggunakan purposive sampling. Teknik pengumpulan data menggunakan teknik wawancara dan observasi. Teknik analisis data dilakukan secara interaktif atau terus menerus. Pengujian keabsahan data menggunakan member check dan triangulasi. Hasil: Hasil penelitian didapatkan bahwa kehidupan pasien stroke dengan bedrest di kategorikan menjadi 4, yaitu dari segi aktifitas sehari-hari, kondisi sosiall, kondisi psikologis dan kondisi spiritual. Pembahasan: Berdasarkan penelitian di atas menunjukkan bahwa pasien stroke dengan bedrest selama lebih dari 1 tahun mengalami perubahan yang signifikan dari kehidupan sebelum dan sesudah mengalami stroke, mulai dari aktifitas sehari-hari, kondisi sosial, kondisi psikologis, dan kondisi spiritual pasien stroke dengan bedrest lebih dari 1 tahun berbeda-beda, tergantung dari cara keluarga menyikapi perubahan emosional pasien. Disarankan untuk keluarga pada pasien stroke lebih memperhatikan sisi psikologis dan sosial pasien selama proses penyembuhannya. Tidak hanya dari segi pengobatan dan terapi dari dokter, tetapi mulai dari aktifitas dan motivasi dari keluarga akan mempengaruhi kehidupan pasien stroke yang bedrest.
\end{abstract}

Kata Kunci : Kehidupan, Stroke, Prolonged Bedrest

\begin{abstract}
Introduction: Stroke is one of the mayor causes lost of working hour and the worst of life quality. Disability that caused by a stroke not only gives an impact to the patient but also to the family. This study aims to know the way of life (daily activity, psychology condition, social condition and spiritual) stroke patients with bed rest more than 1 year is very important to be analyzed, so we know the real life of patients' stroke in their house. Method: The design of the study was qualitative with phenomenology approach. The instrument comes from the researcher self and objects of the research used purposive sampling. Data collection technique used interview and observation. Data analysis technique used interactively or continues. To crosscheck the real data used member check and triangulation. Result: The result of study gained the life of stroke patient bedrest was category into 4, from daily activity, social condition, pshycologys condition, and spiritual condition. Discussion: Based on the study above showed that stroke patients with bedrest for over 1 year experienced significant changes from life before and after a stroke, ranging from daily activities, social conditions, psychological conditions, and spiritual condition of stroke patients with bedrest over 1 years different, depended on how the family responds to the patient's emotional change. It was recommended for families in stroke patients to pay more attention to the psychological and social side of the patient during the healing process. Not only in terms of treatment and therapy from doctors but start from the activity and motivation from family influenced the stroke patient life of bedrest.
\end{abstract}

Keywords: Life, Stroke, Prolonged Bedrest 


\section{PENDAHULUAN}

World Stroke Organisation (WSO) tahun 2009, melaporkan bahwa stroke adalah penyebab utama hilangnya hari kerja dan kualitas hidup yang buruk, kecacatan akibat stroke tidak hanya berdampak bagi pasien, namun juga bagi anggota keluarga. Serangan stroke di masyarakat sering dianggap bencana karena menimbulkan kegagalan fungsi tubuh (Lumbatobing,1998). Hal ini berdampak pada kehidupan biologi, psikologi, sosial, ekonomi, dan spiritual pasien. Hal inilah yang menimbulkan stigma yang buruk tentang stroke di masyarakat.

Kejadian stroke di Indonesia bahkan di dunia semakin lama semakin meningkat. Berdasarkan data terbaru pada tahun 2016 di paviliun flamboyan RSUD Jombang, tiap bulannya kurang lebih 139,9 orang terkena stroke dan diperoleh total jumlah pasien stroke sebanyak 1.678.

Ketidakmampuan bekerja maupun beraktifitas secara normal kembali, kegiatan sosial yang berkurang merupakan akibat kelumpuhan dan kecacatan fisik karena serangan stroke. Hal itu mengakibatkan harga diri pasien menjadi rendah, tidak percaya diri untuk melakukan aktifitas kembali seperti sedia kala karena kondisi fisik yang berubah dan cacat. Bahkan pasien stroke juga bisa mengalami depresi apabila kurangnya dukungan keluarga dan merasa bahwa dirinya hanya menjadi beban keluarga (Tutik,2004)

Proses pemulihan stroke yang sangat lama ternyata akan menumbuhan stressor yang tidak hanya di alami oleh pasien tetapi juga keluarga. Aktifitas yang biasa dilakukan oleh keluarga yang merawat akan menjadi terhambat, karena waktu yang di butuhkan untuk proses perawatan pada anggota keluarga yang menderita stroke dalam sehari akan memakan waktu yang cukup lama. (Van Exel dkk,2005).Maka dari itu peran keluarga sangatlah di butuhkan untuk memberikan perawatan lanjutan dan memenuhi kebutuhan perawatan diri pasien.

Berdasarakan uraian tersebut, maka explorasi tentang bagaimana kehidupan (aktifitas sehari-hari, kondisi psikologis, kondisi sosial dan spiritual) pasien stroke dengan bedrest selama $>1$ tahun sangat perlu untuk di teliti, sehingga dapat diketahui bagaimana sesungguhnya kehidupan pasien stroke di rumah. Untuk itu peneliti perlu untuk mengkaji lebih dalam tentang kehidupan pasien stroke dengan bedrest ini.

\section{METODE PENELITIAN}

Desain penelitian dalam penelitian ini adalah Penelitian Kualitatif dengan pendekatan Fenomenologi, yang merupakan suatu metode penelitian yang berlandaskan pada filsafat postpositivisme, digunakan untuk meneliti kondisi pada objek yang alamiah (Sugiyono, 2009). Instrumen dalam penelitian ini adalah peneliti sendiri. Subjek pada penelitian ini, Peneliti menggunakan puposive sampling dengan mengkhuskan pada subjek yang sesuai dengan purpose atau tujuan dari penelitian ini sesuai dengan latar belakang penelitian ini. Teknik pengumpulan data yang digunakan dalam penelitian ini adalah menggunakan teknik wawancara dan observasi.

Penelitian dilaksanakan pada minggu keempat bulan Maret hingga minggu ketiga bulan April 2017, waktu pelaksanaan dilakukan pada pagi, siang, sore atau malam hari di tempat tinggal informan yaitu di Desa Pucangsimo Kecamatan Bandarkedungmulyo Kabupaten Jombang yang sudah mendapat persetujuan dari informan. Untuk mengetahui kehidupan pasien stroke dengan prolonged bedrest ( $>1$ tahun), peneliti menggunakan teknik analisis data, yaitu:reduksi data, penyajian data, dan conclusion drawing/ verification

Dalam penelitian ini menggunakan analisa data sesuai prosedur colaizzi (Beck, C. $\mathrm{T}$ dalam Kurdi, 2016). Serta menggunakan beberapa tehnik pengujian keabsahan data, yaitu: member check dan triangulasi

\section{HASIL DAN PEMBAHASAN}

Hasil penelitian menghasilkan 4 tema utama yang memberikan suatu gambaran mengenai kehidupan pasien stroek dengan prolonged bedrest. Bab ini akan menjelaskan tentang gambaran karakteristik partisipan dan membahas tentang analisa kehidupan pasien stroke dengan prolonged bedrest.

\section{Deskripsi informan penelitian}

1. Informan R01

Ny.R saat ini berusia 58 tahun, dan seorang ibu rumah tangga, Ny.R merupakan anak terakhir dari 8 bersaudara. Ibu dan kakak ke dua Ny.R mempunyai riwayat penyakit yang sama dengan Ny.R yaitu stroke dan sudah meninggsl. Ny.R merupakan salah satu pasien stroke dengan bedrest kurang lebih selama 2 tahun. Beliau mengalami stroke akibat kadar 
kolesterol yang sangat tinggi. Di dalam kehidupan sehari harinya Ny.R di bantu oleh anak dan suaminya di rumah. Tidak ada yang bisa dilakukan Ny.R sendirian kecuali ada yang membantu karena sebagian tubuhnya mengalami kelumpuhan atau kelemahan fisik akibat stroke.

Ekonomi keluarga Ny.R (responden 01) semakin menurun setelah mengalami stroke. Banyak biaya pengobatan untuk proses pemulihan Ny.R yang menguras biaya kebutuhan keluarganya.

\section{Informan R02}

Ny.I dulunya seorang ibu rumah tangga biasa. Ny. I berusia 70 tahun. Hasil wawancara dengan Ny.I mengenai silsilah keluarga dan riwayat penyakit keluarga adalah Ny.I merupakan anak ke10 dari 12 bersaudara. Hampir semua saudara Ny.I yang meninggal akibat penyakit yang sama. Ny.I terkena stroke akibat hipertensinya yang sudah lama di derita. Ny.I mengalami stroke kurang lebih 14 bulan. Beliau di rawat oleh anaknya di rumah dengan kondisi bedrest total di tempat tidur. Kegiatan sehari hari juga harus dengan bantuan anaknya karena Ny.I megalami kelemahan fisik pada bagian tubuh sebelah kanan (tangan kanan dan kaki kanan). Lamanya bedrest mengakibatkan kondisi psikologis Ny.I menjadi tidak terkontrol.

Keluarga merasa bahwa ekonomi keluarganya semakin lama semakin menurun. Di tambah lagi kebutuhan Ny.I yang semakin meningkat akibat stroke dengan bedrest ini. Tidak hanya pengeluaran dari obat yang dikonsumsi Ny.I tetapi juga keperluan seperti pempers, dll untuk memenuhi kebutuhan Ny.I selama bedrest ini. Maka, keluarga Ny.I memutuskan untuk menghentikan pengobatan untuk Ny.I ke dokter dan rumah sakit. Keluarga Ny.I lebih memilih untuk merawat Ny.I di rumah dengan cara mereka sendiri

3. Informan R03

Tn. $\mathrm{N}$ berusia 69 tahun. Tn. $\mathrm{N}$ merupakan anak ke lima dari tujuh bersaudara. Dari keterangan yang di dapatkan dari Tn.N tentang riwayat penyakit keluarga, ternyata saudara Tn.N mempunyai riwayat penyakit yang sama. Tn.N merupakan satu satunya tulang punggung keluarganya. Maka, saat stroke ketiga ini, membuat Tn.N tidak bisa melakukan aktivitas seperti dulu karena kondisinya yang bedrest. Semua aktivitas hanya bisa dilakukan di tempat tidur dan harus dibantu dengan istrinya. Stroke juga mempengaruhi kondisi ekonomi keluarga Tn.N yang mengalami penurunan.

\section{Deskripsi Hasil Penelitian \\ A. Kehdupan Pasien Stroke Dengan Prolonged Bedrest}

1. Pengalaman Aktifitas Sehari hari

Wawancara mengenai bagaimana aktifitas sehari hari pasien stroke dengan bedrest, Peneliti memberikan pertanyaan mengenai bagaimana kegiatan sehari hari selama bedrest $>1$ tahun. Berikut jawaban singkat dari Ny.R yang di sampaikan kepada peneliti.

"makan terkadang di kursi roda tetapi kadang ya hanya di tempat tidur saja mbak" lalu, keluarganya menambahkan pernyataan dari Ny.R untuk menjelaskan bagaimana saat BAB dan Bak, serta pola tidurnya. "kalau BAB BAK di pakaikan pempers mbak, kalau sore, setelah ashar itu di pakaikan pempers, kalau siang ya tidak, ya biarkan di sini saja (memegang tempat tidur yang di lapisi perlak) di bersihkan saja, karena tidak ada dananya itu mbak buat pempers e, jadi ya di buat sehari sekali begitu saja, lalu tidur nya tidak ada masalah, malahan sering tidur nya ibu itu."

Informan R02 dan R03 hampir memiliki pengalaman aktivitas yang sama dengan R01, mulai dari pola tidurnya, BAB dan BAK. Tetapi berbeda di cara mereka makan, untuk R02 selalu makan di tempat tidur dengan posisi setengah duduk, sedangkan R03 di tempat tidur dengan posisi terlentang dan hanya minum jus 2.Kondisi Sosial Pasien Stroke

Selanjutnya peneliti bertanya bagaiamana kondisi sosial pasien stroke selama bedrest. Ny.R dan Ny.I sama sama menjawab bahwa stroke memang menjadi penghalang dalam bersiosialisasi dengan tentangga atau saudaranya. Kemudian Ny.R menjawab sebagai berikut:

"biasanya di temani anak saya, suami saya, terkadang anak saya yang pertama ya kesini."

tetapi Ny.R ini selama stroke ini juga jarang berbicara, tidak ada kemauan untuk bercerita ataupun bertanya. hanya bicara seperlunya dan tidak berbicara apabila tidak di ajak bicara. karena pasien kemampuan berfikirnya berkurang akibat stroke.

Sedangkan Ny.I (R02) merasa dirinya tidak bisa lagi berkumpul dengan tetangga, 
jarang berkumpul dengan keluarga akibat kondisinya yang seperti ini. jarang ada saudara Ny.I yang datang menjenguk. Selanjutnya hasil wawancara yang peneliti lakukan pada informan 03 yang memberikan keterangan yang sedikit berbeda dari informan 01 dan 02. Tn.N mengatakan bahwa kondisi stroke ini tidak menjadi penghalangnya untuk berkomunikasi dan berinteraksi dengan tetangga.

"tidak ada masalah dengan tetangga, kalau anak saya dan sodara kadang kadang masih silaturahmi ke sini"'(R03)

Maka didapatkan hasil penelitian bahwa kondisi sosial pasien stroke dengan prolonged bedrest rata-rata mengalami penurunan dalam interaksi sosialnya. Menurut diagnosa NANDA-International 2012-2014 juga menyebutkan bahwa hambatan interaksi sosial berhubungan dengan salah satu faktor yaitu hambatan mobilitas fisik

\section{Kondisi Psikologis Pasien Stroke}

pasien yang terkena stroke dengan bedrest $>1$ tahun, mereka pasti mempunyai perasaan yang yang berbeda-beda. Menurut keluarga, informan R01 seperti berfikir bebas, tidak merasa sedih, juga tidak pernah merasa senang selama stroke ini. Sedangkan informan 02 terkadang merasa jenuh dengan kondisinya yang tidak ada perubahan selama lebih dari 1 tahun bedrest. Ny.I sering menangis saat ada saudara yang menjenguknya. Ny.I juga pernah mengatakan ingin ikut adiknya yang baru saja meninggal karena sudah tidak tahan dengan kondisinya yang seperti ini.

"saya lebih baik mati saja, ikut yuk.nah saja."(R02).

Pada umumnya pasien stroke tidak bisa mengontrol emosinya, sehingga terkadang mereka merasa kesepian, mudah tersinggung, sedih, dan mudah marah. Seperti pernyataan informan 02 ini:

"kadang marah mbak, saya jenuh dengan keadaan yang begini saja. saya ingin cepat bisa berjalan lagi mbak, lalu saudara saudara juga jarang yang datang ke rumah."

Pada saat wawancara dengan Tn.N juga didapatkan hasil yang sama, bahwa Tn.N terkadang marah apabila permintaannya tidak terpenuhi. Berikut apa yang yang dikatakan Tn.N (R03) mengenai kondisi emosionalnya:

"kalau tidak di turuti kemana mana, pusing, jadi saya marah mbak, karena tidk bisa kemana mana."

Tidak heran bahwa rata-rata kondisi emosional pasien stroke dengan prolonged bedrest berubah, karena menurut Benny (2008),Bogousslavsky tahun 2003

melaporkan berbagai perilaku dalam suatu kohort pasien stroke menggunakan the Emotional Behavioral Index. Didapatkan bahwa kesedihan, kurangnya adaptasi, menarik diri dari lingkungan, menangis, pasif, dan agresifitas merupakan manifestasi perubahan kepribadian dari pasien stroke.

\section{Kondisi Spiritual Pasien Stroke}

Dengan kondisi yang masih dalam keterbatasan dan sangat membutuhkan bantuan orang lain dalam setiap aktivitasnya, Maka peneliti juga perlu menanyakan bagaimana kondisi spiritual pasien stroke. Pertama jawaban dari Ny.R (informan 01) adalah sebagai berikut

"tidak bisa sholat mbak, sholawat saja terus."

Informan 01 seperti tidak ada keinginan untuk sholat, karena mengalami penurunan cara berfikir akibat stroke. Sedangkan informan 02 dan 03 tetap berusaha untuk memenuhi kebutuhan spiritualnya, karena keluarganya yang selalu mengingatkan. "masih sholat kok mbak. tapi ya dengan berbaring dan anak saya yang mengingatkan."

Hanya saja informan 03 terkadang sulit untuk diingatkan karena eosionalnya yang tidak terkontrol.

Diagnosa NANDA-International 20122014 juga menyebutkan bahwa perubahan hidup menjadi salah satu faktor yang berhubungan dengan distress spiritual. Maka dari itu pasien stroke sudah tidak tahu waktu beribadah dan harus selalu diingatkan. Menurut Asmadi (2008) Immobilisasi yang lama bisa menyebabkan kemampuan klien untuk mengembangkan aktivitas intelektual dapat menurun, sehingga pasien stroke tidak ada keinginan untuk memenuhi kebutuhan spiritualnya kecuali jika diingatkan oleh keluarganya

\section{Kesimpulan}

Berdasarkan penelitian kualitatif yang sudah dilakukan dengan teknik observasi, 
wawancara, dan dokumentasi yang dilaksanakan di Desa Pucangsimo Kecamatan Bandarkedungmulyo Kabupaten Jombang dapat diambil kesimpulan sebagai berikut:

1. Kehidupan pasien stroke dengan bedrest setiap orang berbeda, tergantung dari cara pasien dan keluarga menyikapi dan menjalani musibah yang di alaminya. Tetapi sebagian besar keluarga yang merawat pasien stroke hanya sekedar membantu untuk memenuhi kebutuhan dasar pasien sampai terpenuhi, dan tanpa di sadari mereka menghiraukan kondisi psikologis dan emosional pasien.

2. Dalam komunikasinya, pasien lebih sering berdiam diri, dan berbicara seperlunya apabila ada orang yang mengajak bicara.

3. Dari kebutuhan spiritual pasien stroke dengan bedrest juga menjadi tidak terpenuhi. Tetapi pasien tidak merasakan bahwa dirinya masih kurang dalam pemenuhan kebutuhan spiritual.

4. Pasien dengan stroke ini sangat ingin diperhatikan, apabila komunikasi dan perhatian yang di berikan keluarga terhadap pasien stroke kurang, mereka akan mudah merasa tersinggung, marah tanpa sebab

5. Stroke dengan bedrest tidak hanya mempengaruhi kondisi fisik dan psikis pasien dan keluarga, tetapi juga bisa mempengaruhi kondisi ekonomi keluarga, karena kebutuhan untuk pasien yang semakin banyak.

\section{Saran}

1. Perlu di lakukan HE (Health Education) tentang pola dan gaya hidup yang sesuai dengan masyarakat yang mempunyai riwayat penyakit hipertensi dan kolesterol, agar tidak sampai terjadi stroke berulang.

2. Keluarga maupun orang orang di sekiling pasien sebaiknya selalu memperkenalkan diri tiap bertemu dengan pasien stroke. Karena pasien stroke akan mudah sekali lupa akibat efek stroke yang mempengaruhi intelegensi pasien.

3. Keluarga sebaiknya selalu memberikan semangat, mengajak bicara dan bercanda pada pasien stroke agar pasien tidak mudah jenuh dan marah.

4. Keluarga maupun orang orang di sekitar pasien stroke sebaiknya selalu mengingatkan pasien tentang ibadahnya, agar pasien tidak mengalami distres spiritual.
5. Dalam institusi pendidikan bisa menjadi referensi buku dengan menambah koleksi buku terbaru agar menunjang referensi penelitian

\section{DAFTAR PUSTAKA}

Asmadi. (2008). 'Teknik Prosedural Keperawatan: Konsep Dan Aplikasi Kebutuhan Dasar Klien". Jakarta: Salemba Medika.

Bastaman. (2007). "Logoterapi Psikologi Untuk

Jakarta: PT.Raja Grafindo Persada.

Chaidir Weillon.(2016)."Kebermaknaan Hidup Pada Pekerja Seks Komersial".Jurnal Psikologi. Sumatera Utara: Universitas Sumatera Utara.

Endriyani Sri. (2014).”Studi Fenomenologi Pengalaman Spiritual Pasien Kusta yang Menjalani Kehidupan di RS Rival Abdullah Palemban "Jurnal Keperawatan Sriwijaya, Volume 1Nomor 1.ISSN No.2355 5459

Exel,V.J et al.(2005).Identification of Caregiver at Risk of Adverise Health Effect.

Hartono, P.D. (2003). "Gangguan depresi pada penderita pasca stroke 8 minggu-3 bulan". Undip:Penelitian bagian Psikiatri FK.Undip

Hasan Syarif. (2012). "Kembali Aktif Pascastroke : Panduan Terapi Mandiri Penderita Stroke Di Rumah".Solo: PT.Tiga Serangkai Pustaka Mandiri

Irfan, Muhammad. (2012)."Fisioterapi Bagi Insan Stroke".Yogyakarta: Graha Ilmu Yogyakarta.

Kurdi, F., 2016. Makna Pencegahan Penularan Human Immunodeficiency Virus (Hiv)/Acquired Immune Deficiency Syndrome (Aids) Oleh Pekerja Seks Komersial (Psk) Di Lokalisasi Klubuk Jombang Studi Fenomenologi (Doctoral dissertation, Universitas Airlangga).

Kurniawati, Pindi. (2010)."Pengalaman Keluarga Merawat Penderita Paska Stroke di Wilayah Pesisir Kota Semarang" Semarang:Universitas Negeri Semarang

Kusnanto.(2006)."Asuhan Keperawatan pada Klien Dengan Lingkup Pemenuhan Kebutuhan Mobilisasi dan Immobilisasi". Surabaya: Universitas Airlangga Surabaya. 
Lumbantobing.(2013). "Stroke: Bencana Peredaran Darah Otak". Jakarta: Badan Penerbit FKUI

Mashudi Sugeng.(2012)."Buku Ajar Sosiologi Keperawatan : Konsep dan Aplikasi". Jakarta: EGC.

Moleong, L. J. (2007). Metodolog Penelitian Kualitatif. Bandung

:Penerbit PT RemajaRosdakarya Offset.

Munawarroh,Sri.(2009)."Penerapan Teori Dorothea Orem Dalam Pemberian Asuhan Keperawatan".Indonesian Publication Index:Jakarta

Muttaqin,Arif.(2008). "Pengantar Asuhan Keperawatan Dengan Gangguan Sistem Persarafan". Salemba: Jakarta.

Pearce Gemma, Pinnock Hillary, Epiphanlou E. Parke HL, Heavey E, Griffiths CJ et al.(2015)."Experience of Self Management Support Following a Stroke: A-Meta Review of Qualitative Systematic Review".PloSONE 10(12): e0141803.doi:10.1371/journal.po ne. 0141803

Polite Denise F, Beck Cherly T.2010."Essentials Of Nursing Research Sevent Edition:Appraising Evidence For Nursing Practice". China: the Point

Pudiastuti, Ratna Dewi.(2013)."PenyakitPenyakit Mematikan".Yogyakarta: Nuha Medika

R.Budiman Yosep.(2013)."Pedoman Standart Pelayanan Medik dan Standart Prosedur Operasional Neurologi".Bantul: Refika Aditama.

Rendy M.Clevo, TH Margareth. (2012)."Asuhan Keperawatan Medikal Bedah Dan Penyakit Dalam".Yogyakarta: Nuha Medika.

Robert, Mundle.(2012).”Engaging Religious Experience in Stroke Rehabilitation". $J$ Relig Health 51:986998.DOI 10.1007/s10943-010-9414-z.

Romahorbo Monica.dkk,(2014)."60 Hal Tentang Perawatan Stroke Di Rumah". Jakarta: GAIA.

Samuel.(1982)."Psikologi Pendidikan II". Jakarta: Lembaga Penerbit FE-UI.

Silaen Benny M, Rambe Aldy S, Nasution Darulkufni.(2008)."Hubungan Antara Perubahan Kepribadian Pasien Pasca
Stroke Dengan Ansietas dan Depresi

Pada Pengasuh".Majalah Kedokteran Nusantara.Volume 41 No.1..

Sugiyono.(2015)."Metode Penelitian Kuantitatif dan Kualitatif: cetakan 2". Bandung: CV.Alfabeta

Suyono, (2006), Yastroki tangani masalah stroke di Indonesia, http://.yastroki.or.id. diakses tanggal 26 Oktober 201.

Tutik.(2004)."Pengaruh Managemen Stres Terhadap Kesiapan Pasien Stroke dan Keluarga Dalam Merencanakan Perilaku Adaptif Pasca Perawatan di Rumah Sakit".Jurnal Keperawatan Indonesia, Volume 8. No.1: 13-17.

Wikipedia.(2007).Bedrest,Wikipedia The Free Encyclopedia.diakses pada tanggal 10 Januari 2017. 